\title{
ARGUMENT „ZE SKOŃCZONOŚCI” JAKO WARIANT KOSMOLOGICZNEGO UZASADNIANIA ISTNIENIA BOGA
}

\begin{abstract}
Streszczenie. W artykule analizuję pewną odmianę kosmologicznej argumentacji za istnieniem Boga - „dowód ze skończoności”. W punkcie wyjścia opieram się na intuicjach Georga W.F. Hegla, które rozwijam. W swoich heglowskich inspiracjach ograniczam się do Wykładów z filozofii religii (t. 1 i 2). W konkluzji wskazuję na niebezpieczeństwo pomieszania porządku poznawczego (skończone jako przesłanka „dowodzenia” realności nieskończonego) z porządkiem ontycznym (domniemana zależność nieskończoności - w szczególności tej realizującej się w Bogu - od tego, co skończone).
\end{abstract}

Słowa kluczowe: skończone; nieskończone; wieczne; odwieczne; finityzm; infinityzm; Bóg; Dobro

1. Postawienie problemu: „indukowanie nieskończoności”. 2. Bóg a nieskończoność. 3. Nieskończoność świata a nieskończoność Boga. 4. Fenomenologiczne podstawy infinityzmu. 5. Nieskończoność absolutna Boga. Dwa porządki. 6. Teleologia i pragmatyka. 7. Zakończenie.

„(...) najbardziej konkretnym określeniem skończoności bytu jest przypadkowość, a tak samo nieskończonością bytu w jej najbardziej konkretnym określeniu jest konieczność"1.

\section{POSTAWIENIE PROBLEMU: „INDUKOWANIE NIESKOŃCZONOŚCI”}

Za pewną odmianę argumentacji kosmologicznej można uznać „dowód ze skończoności”. W tym ostatnim - mówiąc najprościej z zakładanego faktu ograniczoności bytu materialnego oraz ludzkiej egzystencji wnosi się o istnieniu nieskończoności (nieograniczoności), a tę ostatnią traktuje się jako kategorię, charakteryzującą właśnie Boga. Przy czym rola samej filozofii - ontologii - jest tu przede

1 Hegel 2007, 443. 
wszystkim negatywna, tj. nie tyle bezpośrednio wskazuje ona na istnienie nieuwarunkowanej i nieskończonej istoty, co „(...) odsłania raczej skończoność tego świata i ujawnia tym samym jego przekraczający sam siebie charakter" (Tillich 1994, 153).

Przytoczmy teraz nieco długą, acz w kontekście podejmowanego problemu charakterystyczną, wypowiedź Hegla: „Świat, skończoność, doczesność, zmienność, przemijalność nie jest tym, co prawdziwe - lecz prawdziwe jest to, co nieskończone, wieczne, niezmienne. Choćby nawet to, co wymieniliśmy, bezgraniczny byt, to, co nieskończone, wieczne, niezmienne, jeszcze nie wystarczało do wyrażenia całej pełni tego, co nazywamy Bogiem, to przecież Bóg jest bezgranicznym bytem, jest nieskończony, wieczny, niezmienny; następuje więc przynajmniej wzniesienie się do tych boskich orzeczników, albo raczej do tych, choćby nawet abstrakcyjnych, to jednak ogólnych podstaw jego natury, a przynajmniej do ogólnego gruntu, do czystego eteru, w którym mieszka Bóg” (Hegel 2007, 435).

Ogólną wskazówkę do rozważań prowadzonych w tym punkcie znajdujemy także u Pannenberga, który pisze: „Pojęcia bytu skończonego jako takiego nie można sobie zatem pomyśleć, nie wspólmyśląc zarazem nieskończoności - nie zawsze wyraźnie, ale przynajmniej konotatywnie: dopiero refleksja nad skończonością bytu skończonego prowadzi do wyraźnej idei nieskończoności” (Pannenberg 1995, 160).

Krótko zaś mówiąc: skończone stworzenie odsyła do nieskończonego Stwórcy. Podstawę dla tego typu uzasadniania istnienia Boga stanowi niewątpliwie nasze codzienne doświadczenie świata. Jak pisze Hegel: „Wszędzie znajdujemy jakiś koniec” (Hegel 2007, 169)2. W świecie materialnym zawsze jest tak, że jedno ograniczone jest przez inne. Zgodnie z ontologiczną zasadą odrębności („wyłączonego środka”): jest ten oto byt lub nie ten oto (inny) byt, zasięg jednego

2 Abstrahuję tu od - zgodnego z duchem materializmu - przypisywania atrybutu nieskończoności samej materii, która miałaby być sama w sobie odwiecznym bezkresem. 
przedmiotu kończy się tam, gdzie zaczyna się inny przedmiot ${ }^{3}$. „Już przez to - wskazuje Hegel - że mamy jakiś przedmiot, jesteśmy skończeni: gdzie on się zaczyna, mnie nie ma, jestem więc skończony" (Hegel 2006, 169). Siłą i wartością ducha - dodaje niemiecki filozof - jest przy tym to, iż duch zna swoje granice. W zasadzie ta wiedza ma już miejsce na poziomie bytu organicznego: „to, co żywe, doznaje strachu, trwogi głodu, pragnienia itd., w jego poczuciu siebie jest przerwa, negacja i jest jej poczucie" (Hegel 2006, 169). Gdyby - argumentuje Hegel - samo to negatywne poczucie ograniczenia i zależności było czymś konstytutywnym dla religii, to także zwierzęta miałyby religię (Hegel 2006, 169). Skoro zaś nie mają, a mają ją ludzie, to w przypadku tych ostatnich - obok wskazywanego wyżej momentu negatywnego - pojawić się musi jakieś pozytywne odniesienie do nieskończoności. Zwierzęta, doznając skończoności i ograniczenia, nie mają zapewne „instynktu nieskończoności", a człowiek go ma. Wynika to zapewne z rozumnej i duchowej jego natury $-z$ tego, że wykracza on w swym myśleniu poza teraźniejszość oraz poza perspektywę najbliższej przyszłości i przeszłości. Źródła ludzkiego wybiegania ku nieskończoności są zapewne co najmniej dwojakiej natury: intelektualnej, czyli oparte na rozumowaniu, oraz fenomenologicznej, czyli opierające się na pewnej intuicji: na wewnętrznym doświadczaniu samego siebie i związanej tym doświadczeniem samoświadomości i intuicji własnego nieskończonego trwania indywidualnego ${ }^{4}$.

Nie przesądzając o pierwotności któregoś z tych źródeł, wskażę, że intelektualną podstawę do myślenia o nieskończoności stanowi swoiste rozumowanie indukcyjne, zgodnie z którym przechodzimy od

3 Można tu rzecz jasna postawić problem nieograniczoności niektórych przedmiotów, jak np. oddziaływania (czy może lepiej - pola) grawitacyjne lub elektromagnetyczne. Jednak np. zasięg oddziaływania grawitacyjnego określonej masy wydaje się być ograniczony. To samo można powiedzieć o określonym ładunku elektrycznym i o generowanym przez niego polu.

4 Patrz niżej. 
jednej granicy ku następnej. W myśleniu o rzeczywistości i o kolejnych granicach, jakie w niej napotyka, człowiek - choć jego doświadczenie dysponuje zawsze tylko skończonym horyzontem - myślowo (matematycznie) ekstrapoluje relację graniczenia z poza ten horyzont. Używając słów Hegla, można powiedzieć: „Dla człowieka granica ta istnieje tylko o tyle, o ile wykracza on poza nią; w poczuciu, $w$ świadomości granicy zawarte jest bycie poza nią” (Hegel 2006, 169). Wprawdzie taka indukcyjnie ugruntowana nieskończoność jest tylko nieskończonością potencjalną (możliwość rozciągania granicy poza wszelkie granice - zawsze jest jakieś „dalej”), ale ona właśnie nasuwa myśl o nieskończoności aktualnej jako swoim warunku: możliwość realizuje się w rzeczywistości, a więc skoro mogę wyjść poza każdą granicę ku następnej, to - jak można podejrzewać - ta następna jest już zaktualizowana ${ }^{5}$. To, że nieskończoność aktualna jest ontologicznie „mocniejsza” niż - opierająca się każdorazowo na czymś skończonym - nieskończoność potencjalna, można by uzasadniać, odwołując się do tezy Hegla, że wywodzenie nieskończoności z tego, co skończone, nie oznacza, że to ostatnie jest „czymś afirmatywnym”. W przeciwnym wypadku uzyskalibyśmy twierdzenie: „(...) byt skończony jest jako skończony nieskończony (...)” (Hegel 2007, 466). Za to, co „afirmatywne” należy uznać nieskończoność - nieskończoność aktualną, gdyż ona obejmuje sobą wszelką skończoność, która nań indukcyjnie wskazuje, lecz nie warunkuje jej. Zarysowywany tu związek skończoności z nieskończonością nasuwa analogię z definicją liczby nieskończonej, jaką podał Gottlob Frege: liczba nieskończona to liczba, przysługująca pojęciu liczba skończona.

U Kartezjusza z kolei znajdujemy myśl o pierwotności idei nieskończoności w naszym umyśle. Nie jest ona tylko wtórnym wytworem

5 Inaczej będzie w przypadku nieskończoności potencjalnej w matematyce, jeśli opowiedzieć się za takim rozumieniem jej dziedziny przedmiotowej, zgodnie z którym matematyk jest nie tyle odkrywcą, co twórcą-konstruktorem. Potencjalnie niekończące się przejście od jednego wyrazu jakiegoś ciągu matematycznego do drugiego będzie bowiem rozumiane jako konstrukcja tego ostatniego - jako tworzenie czegoś, co wcześniej nie istniało. 
naszego myślenia - na zasadzie negacji (infinitacji) wywiedzionym z idei bytu skończonego. „(...) pojmuję - pisze Kartezjusz w Medytacjach o fllozofii pierwszej-że więcej rzeczywistości jest w substancji nieskończonej niż w skończonej i że zatem jest we mnie w jakiś sposób na pierwszym miejscu ujęcie nieskończoności przed ujęciem bytu skończonego, czyli ujęcie Boga przed ujęciem mnie samego" (Pannenberg 1995, 161). Przy czym dodać tu należy, że nie znaczy to, iż pojmujemy nieskończoność ,jasno i wyraźnie” („adekwatnie”) i bez odniesienia do skończoności. Przeciwnie, rozumiemy ją w świetle bytu skończonego (tak jak np. o całym morzu myślimy w kontekście widzianego przez nas jego fragmentu), ale jednak jako coś, co chociaż pojmowane mgliście (nieadekwatnie), ma bezwzględne ontyczne pierwszeństwo wobec skończoności (Pannenberg 1995, 161).

Dodam tu jeszcze, że „indukowanie nieskończoności” z poszczególnych przypadków bytów skończonych może mieć zarówno charakter synchroniczny (dotyczący przestrzeni) ${ }^{6}$, jak i diachroniczny (dotyczący czasu). W pierwszym przypadku rozumuje się tak: każde przestrzennie ograniczone graniczy z czymś innym (nie można graniczyć z niczym, z niebytem), co z kolei ograniczane jest przez inne skończone, itd. w nieskończoność. Ściślej mówiąc: wszystko, co przestrzennie skończone, gdzieś się kończy, czyli graniczy z czymś. I teraz to coś jest albo nieskończone (co kończy wywód), albo zawsze skończone, co daje regres w nieskończoność i też w zasadzie kończy sprawę, bo nasuwa myśl o nieskończoności aktualnej, dzięki której możliwe są te kolejne niekończące się ograniczenia. W przypadku diachronii myślenie przebiega tak: każde ginące przeobraża się w coś innego ginącego, itd. w nieskończoność 7 . Dokładniej biorąc: wszystko, co czasowo skończone, albo przeobraża się w coś czasowo

6 I to jest aspekt mniej interesujący - czy zgoła po prostu nieistotny - jeśli chodzi o „dowodzenie" istnienia Boga.

7 Przy czym myślenie to przebiega także wstecz: coś powstało (lub weszło w skład czegoś nowego) z czegoś innego, co wcześniej zginęło, itd. w nieskończoność. 
wiecznotrwałego (rozpad na wiecznotrwałe byty elementarne, filozoficzne atomy) - i mamy nieskończone trwanie, albo zawsze w coś również skończonego - i otrzymujemy regres w nieskończoność, naprowadzający myśl na aktualną odwieczność bytu.

Uogólniając oba punkty widzenia: to, co skończone, posiada granice (swoje ograniczenie przestrzenne lub kres czasowy); posiadanie zaś granicy oznacza dalsze coś (coś co rozciąga się lub trwa dalej), gdyż nic nie może graniczyć z niebytem, którego nie ma (Parmenides). Tak więc kolejne granice w postępie dają nieskończoność bytu.

\section{BÓG A NIESKOŃCZONOŚĆ}

Bezpośrednim rezultatem tego typu myślenia nie jest wprawdzie przeświadczenie o istnieniu osobowego Boga, gdyż jako nieskończony w sensie aktualnym mógłby być pomyślany także materialny wszechświat. Pannenberg zwraca uwagę np. na problematyczność bezpośredniego utożsamiania przez Kartezjusza przedstawienia nieskończoności (które ma poprzedzać wszelkie inne treści świadomości) $z$ ideą Boga. Bowiem nawet jeśli uznamy, że to, co nieskończone, jest doskonalsze od skończonego - że jest ono w najwyższym stopniu doskonałe - nie osiągamy jeszcze przez to idei Boga. Idea najwyższej doskonałości nie jest tożsama z ideą Boga, gdyż w tej ostatniej zawierają się jeszcze momenty osobowego charakteru (samoświadomości i woli). Najpierw trzeba mieć idę Boga (religia), a potem można przypisywać Jemu - na zasadzie wyłączności - atrybuty nieskończoności i najwyższej doskonałości (Pannenberg 1995).

Niemniej nieskończoność jako przymiot jakiegokolwiek bytu jest charakterystyką tak wzniosłą i „mocną”, że może nasuwać (i często nasuwa) myśl o Transcendencji, która jest prawdziwym źródłem 
nieskończoności świata materialnego ${ }^{8}$. Ponadto - jak zauważa Hegel - Boga należy pojmować jako nieskończonego, pozbawionego granicy, ale „nie w sensie złej bezgraniczności, lecz raczej zarazem jako to, co najbardziej określone, czyste samookreślenie (...)" (Hegel 2007, 560). Bóg zatem nie powinien być pojmowany jako tylko czysta nieskończoność, nieokreślony bezkres, swoisty apeiron, lecz jako byt, którego nieskończoność jest jednym $\mathrm{z}$ atrybutów - więcej - która występuje jako dookreślenie każdego atrybutu Boga: nieskończona dobroć, nieskończona mądrość, nieskończona moc.

Wskazane wyżej „indukowanie nieskończoności” (poprzez znoszenie kolejnych granic - zawsze jest ,jakieś dalej”) może być rozpatrywane jako potwierdzające Heglowską tezę, iż to, co skończone, zakłada nieskończoność. „Dokładniejsze - pisze Hegel - wyrażenie tego twierdzenia: jeżeli istnieje coś skończonego, to jest również to, co nieskończone, jest najpierw takie: Byt tego, co skończone, jest nie tylko jego [własnym - M.モ.] bytem, lecz również bytem tego, co nieskończone" (Hegel 2007, 465). Tego typu argumentacje, jak zarysowane wyżej, można by - za Heglem - określić jako „wznoszenie się” tego, co skończone, ku temu, co nieskończone. Nie jest to zatem wiedza bezpośrednia, jaką - jak się twierdzi - można osiągnąć w nastawieniu mistycznym, lecz par excellance zapośredniczona - zapośredniczona bezpośrednim doświadczeniem skończoności i przypadkowości. To te ostatnie momenty, jakie bezpośrednio odkrywamy w świecie i w sobie samych jako w tym świecie umocowanych, stanowią platformę pozwalającą odbić się do lotu ku nieskończoności i konieczności. Zarazem tylko poprzez porzucenie tego punktu odbicia, za pośrednictwem jego negacji jako koniecznego początku, jesteśmy w stanie przybliżyć się do nieskończoności (Hegel 2007, 436). Trzeba przy tym zwrócić uwagę, że jeśli wskazaną wyżej argumentację (w obu jej

8 Analogicznie jak Georg Cantor odróżniał matematyczną nieskończoność różnych zresztą - i nieskończenie licznych - mocy („pozaskończoność”) od prawdziwej i absolutnej nieskończoności in Deo. 
wariantach) uznaje się bez dodatkowych założeń za „dowód” istnienia Boga, to jest to błąd ignoratio elenchi. Ten zaś opiera się na błędzie non sequitur, gdyż z faktu, że skończone implikuje nieskończone (a przypadkowość - konieczność), nie wynika istnienie Boga, a jedynie infinityzm ontologiczny - na przykład typu materialistycznego. Mimo to jednak można się zgodzić uwagą Hegla, że „(...) spekulatywne rozpatrywanie natury tego, co skończone, zapośredniczenia, z którego wynika to, co nieskończone, jest osią, wokół której obraca się całość, wiedza o Bogu i jego poznanie" (Hegel 2007, 465). Zgodę na powyższe opieram na tym, że nieskończoność, którą wywodzimy ze skończoności poszczególnych elementów otaczającej nas rzeczywistości - choć sama w sobie mogłaby być traktowana czysto przedmiotowo i „bezdusznie” (ot po prostu, istnieje nieskończona ilość nigdy nie ginącej - a jedynie transformującej się - materii-energii), to jednak stawia myślicieli przed pytaniem, skąd biorą się nieskończone wymiary bezwładnej materii, i nasuwa wątpliwość - sygnalizowaną już zresztą wyżej - czy jest to atrybut materii immanentny, czy te $\dot{z}$ pochodzi od wyższej „duchowej siły”, której prawdziwie samoistną nieskończoność symbolizuje.

\section{NIESKOŃCZONOŚĆ ŚWIATA A NIESKOŃCZONOŚĆ BOGA}

W standardowych wykładniach teologicznych nieskończoność świata materialnego uznaje się za kolidującą $z$ naturą nieskończonego Boga - na zasadzie: albo nieskończone stworzenie, albo nieskończony Bóg - względnie za panteistyczne utożsamienie nieskończonego Boga z naturą (ze stworzeniem). Nie widzę tu jednak żadnego konfliktu. Powiem nawet więcej: uznanie nieskończoności wszechświata bardziej harmonizuje $z$ istnieniem transcendentnego ${ }^{9}$ Boga niż założenie skończoności materialnego bytu. Jak już wskazywałem, często

9 A zarazem - na mistycznej zasadzie: wszystko jest w Bogu, a Bóg jest we wszystkim immanentnego Boga. 
rozumuje się tak: skoro Bóg jest naturą nieskończoną, to - a contraristworzony przez niego wszechświat musi być skończony ${ }^{10}$. Ale nie jest to wynikanie konieczne. Nieskończony przestrzennie wszechświat niczego Bogu nie ujmuje ani też w żaden sposób Jemu nie dorównuje. Zakładamy bowiem, że Bóg - jako czysty duch - jest nieprzestrzenny. Nieprzestrzenność zaś Boga należy rozumieć zarówno w tym sensie, że nie posiada On rozmiarów (długości, szerokości, głębokości), jaki i w tym, że nie jest on lokalizowany ${ }^{11}$. Nie ma miejsca - ani w przestrzeni fizycznej tego świata, ani w sferze nieba (jeśli założyć, jak to się często w teologii czyni, istnienie niebiańskiej rzeczywistości, która swą doskonałością przewyższa wszystko, co właściwe jest fizycznemu wszechświatowi, lecz która nie jest miejscem „rezydowania Boga” ani, tym bardziej, samą Boską rzeczywistością, a jedynie wyraźniejszym niż rzeczywistość fizyczna znakiem Jego obecności) - w którym byłby Bóg. Standardowo wyrażamy to, mówiąc, że Bóg jest wszędzie. Jak pisze Filon Aleksandryjski: „Bóg przecież wszystko napełnia i wszystko przenika, i nie pozostawia żadnej próżni i pustki, w której by się nie znajdował" (Filon Aleksandryjski 1986, 136). Rzecz jasna trzeba dodać, że znajdowanie się Boga w świecie stworzonym ma inny sens niż znajdowanie się przedmiotu materialnego w określonym miejscu. Przestrzeń fizyczna nie stanowi dla Boga żadnej bariery. Bóg nie istnieje w miejscu, gdyż nie jest bytem „ogarniętym”, lecz „ogarniającym”. Inaczej rzecz stworzona: „(...) istnieje w miejscu, ponieważ musi być ogarnięta, ale nie musi ogarniać” (Filon Aleksandryjski 1986, 146). Dla ludzi wynika stąd następująca konsekwencja

10 O ile - jak chcieliby panteiści - nie jest z Nim tożsamy.

11 W przeciwieństwie do ducha czystego ludzka świadomość („duch uziemiony”), choć jest nierozciągła (bezwymiarowa), jest jednak lokalizowana. Wątek nierozciągłości, a zarazem lokalizowalności przestrzennej świadomości indywidualnej, poruszam m.in. w pracy O świadomości. Fenomenologia zjawisk umysłowych (Łagosz 2016, 102). Podobnie o duchu ludzkim pisze też Romano Guardini: „Sam duch tak jest niezłożony, że nie zabiera sobą miejsca w przestrzeni. Ma jednak swoje miejsce w przestrzeni i czasie dzięki ciału (...)" (Guardini 1995, 72). 
praktyczna: jeśli człowiek jest ogarnięty przyrodą i nie może od niej uciec, to tym bardziej ogarnięty jest Bogiem (i znów trzeba dodać: nie $\mathrm{w}$ takim sensie, $\mathrm{w}$ jakim jedno ciało otacza drugie czy jeden wycinek przestrzeni fizycznej inny) - nie ma zatem miejsca, gdzie mógłby się przed Nim skryć (Filon Aleksandryjski 1986). Tak więc opisując - co zdarza się nagminnie - relację Boga do świata przy użyciu wyrażeń: „w świecie” czy „ponad światem”, należy pamiętać, że są to tylko przestrzenne metafory, a sam stosunek Boga do świata nie ma charakteru przestrzennego. Stwierdzając to, Tillich proponuje jako właściwe ontologiczne rozumienie tych metafor - interpretację w kategoriach wolności. Sugestię Tillicha rozumiem tak, że ludzka wolność, która - choć skończona - w tak jaskrawy sposób odstaje od rządzącej przyrodą determinacji przyczynowej (zarówno w jej jednoznacznej, jak i statystycznej postaci), jest tym pierwiastkiem Boskim, który przenika rzeczywistość stworzoną ${ }^{12}$; jest jawnym śladem obecności Boga „w” świecie. Z drugiej zaś strony Bóg jest radykalnie transcendentny wobec świata, co - odwołując się do wolności - można z kolei interpretować tak, że w swej wolności człowiek może działać - i faktycznie to robi - „wbrew swojej istotowej jedności z Bogiem” (Tillich 1994, 124). Można powiedzieć, że nieskończona dobroć absolutnie wolnego Boga i skłonność „uziemionej” ludzkiej wolności do zła, czynią człowieka i Boga radykalnie wzajemnie transcendentnymi.

Nie ma zatem płaszczyzny porównania miedzy Bogiem a nieskończonym przestrzennie stworzeniem. Nieskończoność przestrzenna nie jest żadną doskonałością, która mogłaby rywalizować z przymiotami doskonałego Boga. Przy czym - co należałoby dodać - z kosmologicznego punktu widzenia nie jest rzeczą pewną, czy materialny wszechświat jest rzeczywiście przestrzennie nieskończony ${ }^{13}$.

12 I znów słowo „przenikanie” ma konotacje przestrzenne, dlatego jest tylko metaforą.

13 Problem nieskończoności przestrzennej oraz czasowej wszechświata rozważam w książce Ontologia. Materializm i jego granice, gdzie opowiadam się za nieskończonością w obu aspektach (Łagosz 2019, 293-309). 
W każdym razie w klasycznym modelu wszechświata ekspandującego dopuszcza się, iż jego ekspansja może (co zależy od wielkości średniej gęstości materii we wszechświecie) zachodzić w nieskończoność. To zaś oznaczałoby co najmniej czasową nieskończoność wszechświata.

Także nieskończoność czasowa (odwieczność) stworzenia nie stawia go na równi z Bogiem, gdyż nie samo nieskończone istnienie jest doskonałością bytu absolutnego, lecz bytowa pierwotność i samodzielność. Nieskończony czasowo wszechświat może (powinien) być pojęty jako zasadniczo wtórny i niesamodzielny, tj. zależny w swej nieskończonej egzystencji od Boga. Gdy już wyjaśniło się, że nie istnieje konflikt między nieskończonością przestrzenną lub/i czasową wszechświata a nieskończonością absolutną Boga, zapytajmy o racje, dla których wszechświat miałby być raczej nieskończony niż skończony. Jeśli chodzi o nieskończoność przestrzenną, to można argumentować, że Bóg nie chciał (nie mógł?) stworzyć bytu ograniczonego - wszechświata, który gdzieś się kończy - gdyż nie wiadomo, na czym miałby się on kończyć. Graniczy się zawsze z czymś. Taką granicą dla świata stworzonego nie może być jednak Bóg, gdyż Ten nie podlega - jak domniemujemy - charakterystyce przestrzennej. Trudno zatem powiedzieć, że „dotąd jest wszechświat, a odtąd Bóg"14. Trudno także pojąć, że byt stworzony graniczyłby z niebytem. Jak wskazywał bowiem Parmenides z Elei: jest byt, a niebytu nie ma. Interpretując to teologicznie, można powiedzieć, że domeną Boga jest byt, a Boska Natura czy boskie pochodzenie czegokolwiek wyklucza niebyt.

Odnośnie zaś do nieskończoności czasowej, to racją przemawiającą za tym, że stworzony wszechświat jest współodwieczny Bogu, jest to, że Bóg nie podlega czasowi; Jego dynamika jest - by wypowiedzieć rzecz paradoksalnie - aczasowa. W związku z tym trudno utrzymywać, że najpierw odwiecznie istniał Bóg i w pewnym momencie

14 Tym bardziej że w wielu interpretacjach teologicznych przyjmuje się, że Bóg jest we wszystkim - wszystko „przenika”. 
tego swego odwiecznego istnienia powołał do życia stworzenie. Po pierwsze: dlaczego akurat w tym określonym momencie? Po drugie: do tego hipotetycznego momentu stworzenia musiałaby upłynąć cała wieczność (Bóg z założenia jest odwieczny) - jak więc mogło do niego dojść w skończonym czasie? W związku z tym rzecz należy rozumieć tak, iź świat stworzony (lub raczej nieustannie stwarzany w odwiecznie aktualnej teraźniejszości Boga) jest „w swej substancji” współodwieczny z Bogiem, a czas i historia to ludzki sposób przeżywania dzieła Boskiego stworzenia. Co się miało dokonać, substancjalnie już się dokonało, a tylko zjawiskowo pozostaje in statu nascendi. Przyznam wszak, że tu jest wielki znak zapytania i trudno rozwiązywalne napięcie między odwiecznością (lub lepiej: aczasowością) Boga a historycznością istnienia świata oraz - jeśli odwołać się do teologii chrześcijańskiej - Objawienia (np. Wcielenia) ${ }^{15}$.

Na pewien ciekawy aspekt konfliktu między założeniem nieskończoności czasowej świata a teologią zwraca uwagę Joseph Ratzinger przy okazji omawiania poglądów Bonawentury w tej kwestii. Ten ostatni stwierdza ogólnie - by streścić rzecz za Ratzingerem - „że nauka o wieczności świata pociąga za sobą w sposób konieczny wszystkie dalsze błędy" (Ratzinger 2014, 549). Generalnym zaś argumentem (nietrafionym zresztą z punktu widzenia współczesnej matematyki, gdzie uznaje się nieskończoną hierarchię nieskończonych typów porządkowych ${ }^{16}$ ) jest domniemanie, że „byłoby niemożliwe nadać porządek, temu, co nieskończone” (Ratzinger 2014, 549). Nieskończonym zaś byłby świat wraz ze swym ruchem, gdyby nie było po cząstkowego „pierwszego poruszenia” (Ratzinger 2014,

15 Należy zauważyć, że przypisywana Bogu aczasowość nie musi (a może nawet nie może) być utożsamiana z brakiem wszelkiej dynamiki Jego istnienia. Pewien rodzaj aczasowej dynamiki niektórzy kosmologowie próbują rozwijać w oparciu o tzw. geometrie nieprzemienne (patrz np. Heller 2002); ontologiczną próbę konceptualizacji dynamicznego istnienia Boga podjąłem w artykule Problem (a)czasowości Boga (Łagosz 2020).

16 Nie widzę powodu, dla którego mielibyśmy odmawiać Bogu możliwości porządkowania rozmaitości nieskończonych. 
549). Widać zatem, że - podobnie zresztą jak Arystoteles i Tomasz z Akwinu - Doktor Seraficki odrzuca regressus ad infinitum. Przy czym - odrzucając regres w nieskończoność - Arystoteles i Tomasz nie odrzucają nieskończoności samej. Według nich nieskończony ciąg ruchów ciał nie narusza zakazu regresu w nieskończoność. Jest tak dlatego, że ten ostatni jest niemożliwy tylko w porządku kauzalnym, „nie zaś na płaszczyźnie przedmiotów tej samej rangi, których następowanie po sobie jest tylko natury akcydentalnej" (Ratzinger 2014, 550). Wyjaśniając powyższe rozróżnienie: niedopuszczalny jest regres, polegający na tym, że mamy ciąg zdarzeń, z których każde poprzedzające jest przyczyną poprzedzanego („tuż następnego”) i tak w nieskończoność. Nic nie stoi jednak na przeszkodzie, aby uznać nieskończony ciąg zdarzeń, poprzedzających dane zdarzenie, lecz nie będących we wzajemnych związkach przyczynowych (ogólniej: związkach racji). Główną bowiem przyczyną „złośliwości” (i przeto niedopuszczalności) regresu w nieskończoność zdarzeń powiązanych przyczynowo jest to, że przy „cofnięciu się” przyczyn danego zdarzenia $\mathrm{w}$ nieskończoność (przyczyna przyczyny przyczyny...) trudno byłoby wyjaśnić zaistnienie tegoż zdarzenia. Samo założenie nieskończonego następstwa (bez powiązań kauzalnych) nie niesie takiego zagrożenia, gdyż jak pisze Ratzinger, „w szeregu zaś przyczyn biegnącym od lewej strony ku prawej w rzeczach świata, które tylko akcydentalnie następują po sobie (...) jedność przyczyny jest już w pełni zagwarantowana przez stwierdzenie, że istnieje najwyższy primus movens" (Ratzinger 2014, 550).

Można przypuszczać, że nieskończoność rozpoznawana (domniemywana) w świecie materialnym lub w dziedzinie matematycznej abstrakcji17 odsyła do nieskończoności absolutnej w Bogu. Nieskończoność świata jest przejawem tej ostatniej, lecz nie na zasadzie panteizmu (który w teologii chrześcijańskiej uchodzi za herezję), lecz raczej panenteizmu („wszystko w Bogu”): nieskończony wszechświat,

17 Niezależnie od ontologicznej interpretacji tej dziedziny. 
„Zawarty” w absolutnej nieskończoności Boga, przez nią ogarnięty. Co jednak dokładnie miałoby znaczyć takie „zawieranie się”? Taka „pudełkowa” interpretacja nastręcza szczególnych trudności, jeśli chodzi o nieskończoność przestrzenną wszechświata, gdyż trudno pojąć naturę Boga jako swoistą „nadprzestrzeń” („superprzestrzeń”), ogarniającą (zamykającą w sobie) nieskończoną przestrzeń stworzonego świata. Za to w przypadku nieskończoności czasowej łatwiej pozbyć się interpretacji „pudełkowej” i rozumieć panenteizm raczej jako „wszystko przez Boga”. W tym sensie nieskończoność stworzenia byłaby pochodną nieskończoności Boga, przez tę ostatnią warunkowaną. Można byłoby nawet różnicować obie nieskończoności czasowe, określając nieskończoność Boga jako odwieczność (istnienie bez początku i końca), a nieskończoność stworzenia jako wieczność (istnienie bez końca). Chociaż nie ma w tym wypadku bezwzględnej konieczności. Stworzony wszechświat mógłby być pomyślany jako współodwieczny Bogu, ale przez Niego w tej współodwieczności warunkowany: konstytuowany i utrzymywany $\mathrm{w}$ istnieniu.

Zwróćmy przy tym uwagę, że Hegel wiązał z kategorią nieskończoności inną treść niż matematyczna (ilościowa - nieskończona liczność, nieskończona rozciągłość). Opierając pojęcie nieskończoności na przeciwieństwie do skończoności i stwierdziwszy, że każdy byt skończony jest zależny od innego bytu, skonstatował, że pojęcie nieskończoności z konieczności wyklucza wszelką zależność od czegoś innego. Tak więc prawdziwa (jakościowa) nieskończoność jest tożsama z Absolutem (Bogiem), a jej prawdziwą treścią jest samowystarczalność (Pannenberg 1995).

\section{FENOMENOLOGICZNE PODSTAWY INFINITYZMU}

Jeśli chodzi o przesłanki natury fenomenologicznej (introspekcyjnej) ludzkiego przeczucia nieskończoności, to należy tu wskazać fakt, że - biorąc właśnie rzecz czysto fenomenologicznie - nie dysponujemy doświadczeniem początku ani końca naszej świadomej (duchowej) 
egzystencji. Zacznijmy od początku, o którym każdy z nas wie, że go ma (określony czas poczęcia czy urodzenia), a którego nikt z nas nie pamięta. Poinformowano nas o tym i wystawiono stosowne dokumenty. $Z$ ustaleń nauki zaś dowiedzieliśmy się, że nie tylko każdy konkretny człowiek ma swój początek, ale i gatunek ludzki w ogóle: był taki czas, kiedy po raz pierwszy w historii świata pojawił się osobnik o określonych cechach ludzkich czy raczej najpierw - hominidalnych. Wszystko to uznaje się powszechnie za pewnik. Tyle tylko, że jeśli wziąć samo doświadczenie wewnętrzne, to brak zupełnie przeżycia początku. Nie istnieje świadomość praimpresji - i w gruncie rzeczy istnieć nie może. Jednostkowa świadomość musiałaby bowiem jakoś istnieć uprzednio jako zupełnie pozbawiona jakiejkolwiek treści i stwierdzić w pewnym momencie: oto moja pierwsza „myśl”. Przy czym jest nie tylko tak, że w introspekcji nie odnajdujemy żadnej praimpresji, lecz także żadne doświadczenie zewnętrzne (zmysłowe) nie nasuwa bezpośrednio myśli o tym, że uprzednio istniało coś beze mnie. W widoku gór np. nie ma nic, co sugerowałoby, że istniały one setki milionów lat przede mną. Wniosek, że mogło coś istnieć przed moim życiem świadomym (duchowym), wyciągam dopiero na podstawie odpowiednio zinterpretowanych doświadczeń. $\mathrm{Na}$ przykład: znam od dawna góry i widzę, że ktoś się rodzi; zakładając, że między powstaniem jego embrionu a narodzinami powstała w tym kimś świadomość, wyciągam wniosek, że istniał świat bez tej konkretnej świadomości. Ja z zewnątrz tak to interpretuję, lecz ten nowo narodzony człowiek nigdy swego początku bezpośrednio nie pozna - chociaż będzie o nim poinformowany. Analogicznie jak o nim myślę o sobie i wnoszę, że także mam swój początek w czasie. Jest zatem pewien rozdźwięk między doświadczeniem wewnętrznym, a opartą na empirii wiedzą przyrodniczą. I tak samo rzecz ma się z końcem. Nowo narodzonego wystarczy tylko zastąpić kimś zmarłym. A mówiąc najogólniej - co podkreślają myśliciele już od starożytności - śmierć nie jest faktem w życiu: śmierci się nie przeżywa. Zatem nie może być też w naszym doświadczeniu 
duchowym uświadomienia ostatniego przeżycia, bo aby ono było, trzeba by, paradoksalnie, jakoś po śmierci fenomenologicznie istnieć, tj. doznawać określonych przeżyćc ${ }^{18}$.

Wniosek z powyższego wyciągam taki, że człowiek pozostający w kręgu wewnętrznego doświadczenia (w swej immanencji) może nabyć intuicję (przeczucie) swojego nieskończonego trwania. Potwierdza to także Friedrich W.J. Schelling, który pisze: „Choć idea ta [że życie człowieka sięga aż po początek stworzenia - M.Ł.] może się zwykłemu sposobowi myślenia wydać niepojęta, to przecież każdy człowiek doznaje zgodnego z nią uczucia, jakoby tym, czym jest, był już w najdawniejszej wieczności” (Schelling 1990, 91-92). Krótko mówiąc: symptomy nieskończoności możemy znaleźć w samych sobie. Znając zaś swoje niedoskonałości, wypada nam domniemywać, że źródło naszej nieskończoności bije w Nieskończoności Boga.

Także Hegel wskazuje na intuicyjne (choć nie odnoszące się - jak wyżej - bezpośrednio do doświadczenia wewnętrznego) podstawy wybiegania człowieka ku nieskończoności: „Mając przed sobą świat, czuje [człowiek - M.Ł.], że to nie wystarcza - czucie czuje też to, co myślowe, czy też to, co ma być przedmiotem myśli (...) Nie wystarcza mu to [, co skończone,] jako coś ostatecznego (...)" (Hegel 2006, 320). Postrzegając świat jako zbiorowisko skończonych rzeczy, a siebie samego jako przygodnego i przemijającego, człowiek dysponuje zarazem poczuciem-przeczuciem istnienia czegoś duchowego i Jednego, co na mocy swej natury jest nieograniczone (nieskończone). „Otóż religia polega właśnie na tym, że człowiek szuka racji i podstawy swojej niesamoistności; dopiero mając przed sobą to, co nieskończone, znajduje spokój” (Hegel 2006, 320).

Dodajmy do powyższego, że Hegel proponuje swoistą dialektykę przejścia od skończoności do nieskończoności. W punkcie wyjścia filozof deklaruje, że to, co mnogie, skończone oraz akcydentalne (świat) - ponieważ nie jest tym, co absolutne - ma przeminąć i powrócić

18 Stwierdzić, że określone przeżycie było właśnie tym ostatnim. 
do jednego, nieskończonego i substancjalnego bytu absolutnego ${ }^{19}$. U podstaw tej deklaracji leży założenie, że byt absolutny warunkuje rzeczywistość, a co za tym idzie, że skończoność znajduje swoje umocowanie w nieskończoności. Rozpatrując rzecz w dialektycznym ruchu, należy powiedzieć, że to, co skończone, przechodzi w swoją negację: ma swoją granicę, którą wyznacza określona jakość. Gdy ta ostatnia znika, znika także to, dla czego była to jakość podstawowa. Tak każdy byt skończony przechodzi w swoją negację, w coś innego. „Tym ‘innym' - powiada Hegel - nie jest coś innego skończonego, lecz to, co nieskończone" (Hegel 2006, 323). Tu można by zapytać, dlaczego tym ,innym” dla określonego przedmiotu skończonego nie może być inny przedmiot skończony. Na przykład: zwierzę, tracąc jakość czucia (dotyku), przestaje być czymś żywym, a staje się martwe; dalej ten kawałek materii - tracąc kolejne swoje jakości - przechodzi w inną postać materii martwej itd., itp. Granica przesuwałaby się coraz „dalej”, ale zawsze przebiegałaby między tym, co skończone, a tym, co skończone. Hegel jednak widzi rzecz inaczej: dla skończonego bytu „tym 'innym' - powtórzmy - jest to, co nieskończone” (Hegel 2006, 324). Co więcej, to inne, czyli nieskończone, stanowi istotę bytu skończonego - ten ostatni ma zatem swą istotę poza sobą (Hegel 2006, 324). W jaki sposób - zapytajmy teraz - ujawnia się metafizyczna konieczność takiego odsyłania do nieskończoności. Czy chodzi tu tylko - abstrakcyjnie biorąc - o nieskończony postęp kolejnych ograniczeń tego, co skończone, przez to, co także skończone? Czy też raczej o jakąś „psychologiczną” tęsknotę skończonej samowiedzy: „ta skończona samowiedza nie zatrzymuje się przy tym, co skończone, porzuca to, rezygnuje $\mathrm{z}$ tego i wyobraża sobie to, co nieskończone" (Hegel 2006, 324). Prawdę mówiąc, trudno

19 Ontologia Hegla jest w tym względzie „antyatomistyczna” („antyfaktualistyczna”), gdzie przez atomizm (aktualizm) ontologiczny rozumiem tezę, że rzeczywistość wyznaczana jest przez luźno powiązane ze sobą fakty (zdarzenia), które mają charakter przygodny. Krótko mówiąc za Ludwigiem Wittgenstainem: „Jedno może być faktem lub nie być, a wszystko inne pozostać takie samo" (Wittgenstein 1997, 5). 
w tym uchwycić ten - postulowany przez Hegla - konieczny tok logiczny, założony w pojęciu tego, co skończone, a który prowadzi do uznania, że „prawdą” (jak ujmuje to Hegel) tego, co skończone, jest nieskończoność. Wydaje się, że jedynym momentem, przesądzającym - ontologicznie biorąc - o konieczności przejścia od skończoności ku nieskończoności, jest niemożliwość zaistnienia absolutnego kresu bytu jako takiego, który składa się z poszczególnych skończonych istnień. Mówiąc po Parmenidesowemu: byt jest, a niebytu nie ma, stąd żaden byt poszczególny nie może znaleźć swej granicy w niebycie - nieskończoność ruchu jest konieczna. Pytanie tylko, czy chodzi tu o ruch świata, czy o trwanie Boga, który byłby absolutną granicą (granicą, która sama granic już mieć nie może) dla stworzenia. Heglowskie rozumienie nieskończoności jest jednak na swój dialektyczny sposób jeszcze bardziej złożone. Oto powiada on: „Wynika to z pojęcia tego, co nieskończone: to, co nieskończone, jest negacją negacji (...)” (Hegel 2006, 325). I dalej: „Jeśli określamy negację dokładniej, to jedną jest to, co nieskończone, drugą to, co skończone, a prawdziwa nieskończoność jest jednościq obu [tych momentów - M.Ł. ${ }^{20}$. Dopiero oba te momenty razem stanowią naturę tego, co nieskończone, jego prawdziwą tożsamość; dopiero ta całość jest pojęciem tego, co nieskończone” (Hegel 2006, 325).

\section{NIESKOŃCZONOŚĆ ABSOLUTNA BOGA. DWA PORZĄDKI}

Taką prawdziwą, jedyną nieskończonością absolutną (w odróżnieniu od nieskończoności, rozpatrywanych w teorii mnogości, a zwanych dla odróżnienia od tej jedynej absolutnej - pozaskończonościami) jest Bóg. „(...) Bóg jest - pisze Hegel - jednościq tego, co nieskończone, i tego, co skończone, a całe zainteresowanie kieruje się na to, w jaki

20 Można to rozumieć tak, że to, co skończone, jest negacją (inno-bytem) tego, co nieskończone, a to ostatnie negacją skończoności (negacją negacji). 
sposób szczegótowość i określoność, tzn. to, co skończone, włączone jest w to, co nieskończone" (Hegel 2007, 6).

Można się wobec tego zastanawiać, czy to, co skończone, warunkuje istnienie nieskończoności jako jej warunek konieczny? Czy nieskończoność zawsze musi zakładać skończoność? Gdyby tak było, to ta pierwsza - wbrew swej naturze - podlegałaby poważnemu i chyba niedopuszczalnemu ograniczeniu. O ile jeszcze w odniesieniu do materialnego wszechświata uznanie, iż jego nieskończoność przenika się ze skończonością (wszystkich istnień poszczególnych w jego obrębie - ale już nie jego jako całości), o tyle nieskończoność (odwieczność) trwania Ducha trudno byłoby w jakikolwiek sposób wiązać ze skończonością. Trudno np. uznać, że Bóg jako taki jest nieskończonością, ale Jego poszczególne myśli są „odtąd dotąd”. W dużej mierze problem ten rozświetla sam Hegel, ustawiając swoje rozważania na poziomie epistemologicznym. Mówiąc o dowodzie kosmologicznym, wskazuje na przesłankę, prowadzącą do uznania nieskończoności. Mówi on o „logicznej naturze przejścia”, która ma „formę sylogizmu”: „to, co skończone, zakłada to, co nieskończone, otóż to, co skończone, jest a zatem jest to, co nieskończone" (Hegel 2006, 326). Dalej mówi on, że byt skończony jawi się jako coś, dzięki czemu ugruntowany jest byt nieskończony: „W ten sposób jakiś skończony byt jawi się jako racja i podstawa (Grund)" (Hegel 2006, 326). Idzie tu zatem bardziej o ruch myśli, a nie rzeczywistości - choć taka izolacja aspektów na gruncie totalnej filozofii Hegla może być problematyczna. $Z$ mojego punktu widzenia sensownie jest jednak odróżnić porząaki: bytowy i poznawczy, oraz uznać, że tylko w tym drugim skończone jest warunkiem (przesłanką) nieskończoności. Tym bardziej, że Hegel - rozpatrując rzecz w porządku ontologicznym - stwierdza, że „(..) to, co nieskończone, nie pojawia się za sprawą bytu tego, co skończone, lecz wynika z niebytu tego, co skończone: to właśnie ten [niebyt - M.Ł.] jest bytem tego, co nieskończone" (Hegel 2006, 327). Rozumiem to tak, że ograniczone bytowo to, co skończone (wcześniej czy później przestaje ono istnieć, staje się niebytem), nie ma w sobie ontycznej 
mocy, by fundować to, co nieskończone. Momentem afirmatywnym i pierwotnym w bytowości jest to, co nieskończone, a to jest negacją skończoności (Hegel 2006). Nie jest tak, że oto nieskończoność składa się z poszczególnych bytów skończonych (żadne dodawanie skończonych nie da w rezultacie nieskończonego ${ }^{21}$ - raczej odwrotnie: to nieskończoność może wygenerować z siebie skończone. $\mathrm{Na}$ tej zasadzie z nieskończonego zasobu (zbioru) liczb naturalnych mogę wybrać ten czy inny ich skończony podzbiór ${ }^{22}$. Rozumowanie to potwierdzają słowa Hegla, który pisze: „Jeżeli to, co skończone, zakłada jako przesłankę, to, co nieskończone, to zawarta jest w tym jeszcze, choć nie jest wyrażona, następująca konsekwencja. To, co skończone, jest tym, co zakłada, ale zaktada jako przestankę, tak, że to, co nieskończone, jest tym, co pierwsze $i$ istotne; jeśli dokładniej rozwinąć przesłankę, to [okazuje się, że - M.Ł.] zawarty jest w niej negatywny moment tego, co skończone, i jego odniesienie do tego, co nieskończone" (Hegel 2006, 328). Dodatkowo Hegel potwierdza logiczny - a nie ontologiczny - charakter tezy, że byt skończony jest racją (podstawą, przesłanką) dla bytu nieskończonego, pisząc: „Ale religia zawiera ten tok myślowy [kursywa - M.Ł.], to przejście od tego, co skończone, do tego, co nieskończone, które nie jest przejściem przypadkowym, lecz koniecznym i wynika z samej pojęciowej [kursywa - M.Ł.] natury tego, co nieskończone" (Hegel 2006, 328).

Gdyby jednak próbować powiązać nieskończoność i skończoność (jedność obu tych momentów) w Bogu na drodze ontologicznej, to trzeba by się chyba zwrócić ku odwiecznej relacji Boga ze stworzeniem. Wspomniana wyżej „szczegółowość” i „określoność” tego, co skończone - poprzez odwieczny akt stworzenia (czy raczej: stwarzania) - sprzęgnięta jest ze swym źródłem - z nieskończonością Boga.

21 Dodawanie kolejnych liczb naturalnych do jakiejś liczby wyjściowej da zawsze tylko kolejną skończoną liczbę naturalną.

22 Mogę też wybrać - co należy do istoty nieskończoności - jakiś jego podzbiór nieskończony, np. zbiór wszystkich liczb parzystych. 
Trzeba tu wszakże widzieć, że nieskończoność Boga i skończoność stworzenia mają zupełnie odmienną naturę. Skończoność świata ma naturę fizyczną - czasową i przestrzenną, nieskończoność Boga zaś - duchową; jest substancjalną mocą Ducha-Stworzyciela oraz jego samowiedzą (Hegel 2007, 7).

\section{TELEOLOGIA I PRAGMATYKA}

Warto jeszcze zwrócić uwagę na aspekt teleologiczny argumentacji „ze skończoności”. Ludzie stawiają sobie różne cele. Spojrzenie na historię świata pokazuje jednak, że pomnikami realizacji tych celów są cmentarze, ruiny wspaniałych budowli lub - co w tym wypadku jeszcze bardziej znamienne - upadki albo zagłady wielkich cywilizacji (ludów, narodów). Z biegiem czasu każdy ludzki cel marnieje. Hegel pisze tak: „Skoro opłakujemy niepowodzenie i upadek tak wielu rzeczy wspaniałych, to musimy właśnie wznieść się do wyższego określenia i do wyższego celu. Wszystkie owe cele, bez względu na to, jak bardzo nas one interesują, musimy uważać za skończone, podrzędne, a ich zniszczenie przypisać skończoności” (Hegel 2007, 546-547). Hegel stwierdza - nie będąc w tym bynajmniej oryginalnym (Platon) - że takim najwyższym ostatecznym celem dla świata jest Dobro. Idzie tu przede wszystkim o - związane z człowiekiem dobro moralne. Człowiek jednak - ze względu na swoją skończoność i "naturalność” - nie jest w stanie tego ostatecznego Dobra urzeczywistnić. Ponieważ zaś, zdaniem Hegla, sam rozum narzuca człowiekowi myśl o ostatecznym Dobru, konsekwentnym staje się postulat istnienia Boga, powinność jego istnienia jako gwaranta realizacji rozumowego celu świata. W świecie stworzonym nie widać bowiem przesłanek bezwzględnego panowania Dobra, co więcej Hegel zauważa, że „(...) jeśli dobro w ogóle ma być [dobrem] moralnym i [jako takie] istnieć, to nawet warunkiem i przesłanką tego jest trwałe istnienie dysharmonii; dobro moralne może bowiem istnieć $i$ istnieje tylko w walce ze złem; wymagane jest więc trwałe istnienie wroga, 
tego, co przeciwstawne dobru" (Hegel 2007, 548). Trzeba dodać, że takiego kontrapunktu wymaga tylko dobro, realizowane w świecie stworzonym. Samo bowiem Dobro, utożsamiane z Bogiem, jako byt absolutny nic poza sobą nie wymaga - tym czymś mogłoby być bowiem tylko zło jako odrębna zasada, co kłóci się z pojęciem absolutu. Jeśli źródłem wszystkiego jest Dobro, to zło w ludzkim świecie musi mu być jakoś podporządkowane, co znaczy, że w planie całościowym to zło (ta „dysharmonia”) wnosi swój wkład do panowania absolutnego Dobra. To, co tu powiedziałem, można traktować jako najogólniejsze rozwiązanie złożonego problemu teodycei.

Tutaj zaś chcę jeszcze krótko zastanowić się nad stwierdzeniem, że „Źródłem, w którym cel [dobro jako ogólny ostateczny stan świata - M.モ.] jest uznany, jest myślący rozum” (Hegel 2007, 547). Jaka konieczność metafizyczna determinuje nas do ustanowienia dobra ostatecznego (Dobra) jako najwyższego celu bytowości? Przecież można pomyśleć sobie świat jako nieokreśloną co do celu mieszaninę zdarzeń, z których jedne uznawane są przez nas za dobre, inne za złe - bez wyraźnego wskazania dominanty, która byłaby celem ostatecznym. Człowiek jednak - chociaż ze względu na swoje uwikłanie w naturę ciąży ku złu - za cel obiera sobie zazwyczaj dobro (wyłączywszy przypadek natur demonicznych, które, choćby z powodu stosunkowo niewielkiej skali zjawiska, należy uznać za patologiczne i gatunkowo niereprezentatywne ${ }^{23}$ ). Poza głębokimi socjopatami i dziećmi nawet ludzie czyniący zło rozumieją negatywność swoich czynów i gdzieś w głębi duszy tęsknią do dobra - w przeciwnym razie trudno byłoby ich traktować jak wolne podmioty, lecz raczej jako niszczącą siłę żywiołu. Rozum zaś rozpoznaje, że prawdą, a tym samym celem ludzkiego istnienia, jest dobro. Podstawa dla tego rozpoznania nie ma bynajmniej transcendentalnego charakteru (nie jest aprioryczna), lecz wiąże się z historycznym doświadczeniem ludzkości, które wskazuje jednoznacznie, że polegające na altruizmie dobro

23 Ale przecież bardzo niebezpieczne. 
moralne jest - w przeciwieństwie do swego zaprzeczenia - tym, co buduje harmonijne bytowanie ludzi w społeczeństwie. Roszczeniem zaś rozumu jest, aby dobro, które w świecie ludzkim ma ograniczony (skończony) charakter i jest niepełne, gdyż przeniknięte towarzyszącym mu złem, było nieskończone i osiągało eschatologiczną pełnię wieczności.

\section{ZAKOŃCZENIE}

Konkludując: o kosmologicznej „ścieżce” uzasadniania istnienia Boga można by w duchu Hegla zauważyć, co następuje: otóż odwołując się w punkcie wyjścia do cech świata stworzonego (wskazując na jego celowość, przygodność, skończoność itd.), poznanie staje się ruchem „wznoszącym” - od stworzenia do Boga.

Szczegółowiej Hegel przedstawia kierunki „wznoszenia się” do Boga w dowodach typu kosmologicznego tak: od bytów poszczególnych duch wznosi się do bytu jako takiego, od rzeczy określonych jako skończone - do nieskończoności; jeśli zaś rzeczy te ujęte są zarazem jako realne (czytaj: materialne), to duch ujmuje owo nieskończone jako byt idealny. I dalej: od bezpośredniości istnienia rzeczy jako powierzchownych pozorów - do istoty jako ich podstawy; jeśli zaś ujać rzeczy świata jako czessci - do Boga jako catości; od tego, co zależne (nie oparte na samym sobie) - do samopodtrzymującej się sity czy wreszcie od rzeczy rozpatrywanych jako skutki do ich najwyższej przyczyny. Przy czym wszystkie te określenia, które przeciwstawiają się właściwościom rzeczy tego świata i do których dążymy w argumentacji kosmologicznej, nie wyczerpują bynajmniej natury Boga, gdyż „jest on w sobie jeszcze głębszy i bogatszy, niż one to wyrażają” (Hegel 2007, 441). Tak więc w dowodach kosmologicznych wznosimy się co najwyżej do pewnej abstrakcji Boga, a nie do pełnej konkretności jego bytowości, która - w swej zupełności - pozostaje zawsze tajemnicą (Hegel 2007, 440-441). Przy czym z jednym na pewno trudno się zgodzić z Heglem w tym kontekście: a mianowicie, że wszystkie te 
wyżej wskazane myślowe przejścia „należy nazwać dowodem zupełnie tego samego rodzaju, jak to, co formalnie określane jest tym mianem" (Hegel 2007, 441-442).

W porządku poznawczym to, co skończone (ograniczone, przygodne, niedoskonałe) staje się warunkiem czy też podstawą do wyprowadzenia istnienia Boga. W żadnym jednak razie nie możemy tu iść za sugestią Hegla, który o wspomnianej relacji podstawy pisze: „(...) jest to związek, w którym byt Boga jawi się jako następstwo, jako coś zależnego od bytu tego, co skończone” (Hegel 2007, 166). Porządek poznawczy (logiczny) nie może być tu mylony z ontologicznym. Poznając Boga (jego istnienie) „od strony” stworzenia, wcale nie uzależniamy jego bytu od czynności poznawczych. W poznaniu Bóg jest poznawany, a nie konstytuowany. Przy czym, gdy mówimy w tym wypadku o konstytucji, to mogłoby co najwyżej chodzić o - podkreślaną przez sceptyków i ateistów - konstytucję czysto myślową: Bóg jako wymysł myślenia, a nie ontyczną. Myślenie ludzkie nie ma bowiem takiej mocy - tylko myślenie Boga może być rozumiane jako ontycznie konstytutywne, tj. realnie powołujące coś określonego do istnienia. Zresztą sam Hegel pisze o „nieodpowiedniości ruchu [myślowego], który nazywamy dowodzeniem, w stosunku do tego, co zawarte jest w naszym wyobrażeniu Boga, [mianowicie] że jest on właśnie czymś niewyprowadzonym, czymś, co istnieje po prostu samo w sobie i dla siebie" (Hegel 2007, 166). Moim zdaniem zaś nie jest to żadna nieodpowiedniość, tylko inny zupełnie porządek. Dowodząc istnienia czegoś, trudno wychodzić od realności tego czegoś. Nie tylko w argumentacji kosmologicznej, ale także przecież w typie "dowodzenia ontologicznego" wychodzi się nie od samego istnienia Boga, lecz od pojęcia (idei) Boga. Inna sprawa, że u Hegla byt i jego pojęcie są w zasadzie jednym - ale to specyfika jego systemu, której nie będę tu już analizował. 


\section{BIBLIOGRAFIA}

Filon Aleksandryjski. (1986). Pisma. Tłum. L. Joachimowicz. Warszawa: PAX. Guardini R. (1995). Wolność - łaska - los. Rozważania o sensie istnienia. Tłum. J. Bronowicz. Kraków: Wydawnictwo Znak.

Hegel, G.W.F. (2006). Wyktady z filozofii religii. Tom 1. Tłum. Ś.F. Nowicki. Warszawa: Wydawnictwo Naukowe PWN.

Hegel, G.W.F. (2007). Wyktady z filozofii religii. Tom 2. Tłum. Ś.F. Nowicki. Warszawa: Wydawnictwo Naukowe PWN.

Heller, M. (2002). Poczatek jest wszędzie. Nowa hipoteza pochodzenia wszechświata. Warszawa: Prószyński i S-ka.

Łagosz, M. (2016). Oświadomości. Fenomenologia zjawisk umystowych. Kęty: Wydawnictwo Derewiecki.

Łagosz, M. (2019). Ontologia. Materializm i jego granice. Kraków: Universitas. Łagosz, M. (2020). Problem (a)czasowości Boga. Studia Philosophiae Christianae, 56(1), 79-102.

Pannenberg, W. (1995). Człowiek, Bóg, wolność. Tłum. G. Sowiński. Kraków: Wydawnictwo Znak.

Ratzinger, J. (2014). Rozumienie objawienia i teologia historii wedtug Bonawentury. Tłum. J. Merecki. Lublin: Wydawnictwo KUL.

Schelling, F.W.J. (1990). Filozoficzne badania nad istota wolności i sprawami z tym zwiqzanymi. Tłum. B. Baran. Kraków: Inter Esse.

Tillich, P. (1994). Pytanie o Nieuwarunkowane. Tłum. J. Zychowicz. Kraków: Wydawnictwo Znak.

Wittgenstein, L. (1997). Tractatus logico-philosophicus. Tłum. B. Wolniewicz. Warszawa: Wydawnictwo Naukowe PWN.

\section{THE ARGUMENT "FROM FINITUDE” AS A VARIANT OF THE COSMOLOGICAL JUSTIFICATION OF THE EXISTENCE OF GOD}

Abstract. In this paper I examine a variant of the cosmological argument for the existence of God - the 'proof from finitude', and develop Georg W.F. Hegel's intuitions on this issue. In conclusion, I point out the danger of confusing the cognitive order (the finite as a premise for "proving" the reality of the infinite) with the ontic order (the presumed dependence of the infinite - especially as realised in God - on the finite).

Keywords: finite; infinite; eternal; from eternal; finitism; infinitism; God; the Good 


\section{MAREK ŁAGOSZ}

Uniwersytet Wrocławski, Instytut Filozofii

(Wroclaw University, Institute of Philosophy, Poland)

ORCID: https://orcid.org/0000-0001-8502-4922

marek.lagosz@uwr.edu.pl

DOI: 10.21697/spch.2021.57.A.03

Artykuł jest udostępniany na zasadach licencji Creative Commons (CC BY-ND 4.0 Międzynarodowe). Zgłoszono: 30/10/2020. Zrecenzowano: 17/12/2020. Zaakceptowano do publikacji: 24/04/2021. 